\title{
Major Books by Professor Raphael Levy
}

The Astrological Works of Abraham ibn Ezra. The Johns Hopkins Studies in Romance Literatures and Languages, vol. 8. Baltimore, Md.: Johns Hopkins Press, 1927.

Recherches lexicographiques sur d'anciens textes français d'origine juive. The Johns Hopkins Studies in Romance Literatures and Languages, extra vol. 5. Baltimore, Md.: Johns Hopkins Press, 1932.

Répertoire des lexiques du vieux français. New York: Modern Language Association of America, 1937.

The Beginning of Wisdom, edited in collaboration with Francisco Cantera. The Johns Hopkins Studies in Romance Literatures and Languages, extra vol. I4. Baltimore, Md.: Johns Hopkins Press, 1939.

Chronologie approximative de la littérature française du moyen âge.

Beihefte zur Zeitschrift für romanische Philologie, vol. 98. Tübingen: M. Niemeyer, 1957.

Contribution à la lexicographie française selon d'anciens textes d'origine juive. Syracuse: Syracuse University Press, 1960.

Trésor de la langue des Juifs français au Moyen Age. Austin: University of Texas Press, I964.

In addition to these major contributions, over one hundred scholarly articles were published in American and foreign journals. 
THIS PAGE INTENTIONALLY LEFT BLANK 